\title{
Review essay \\ Hate speech and the normative foundations of regulation
}

\author{
The Content and Context of Hate Speech: Rethinking Regulation and Responses \\ Edited by Michael Herz and Peter Molnar, Cambridge: Cambridge University Press, 2012. $544+x x i v p p$. \\ ISBN 978-0-52113-836-9 £29.99 \\ The Harm in Hate Speech \\ By Jeremy Waldron, Boston, MA: Harvard University Press, 2012. $292+x$ pp. \\ ISBN 978-0-67406-589-5£19.95 \\ Reviewed by Eric Heinze \\ School of Law, Queen Mary, University of London*
}

\section{Introduction}

Racist incidents on American university campuses in the I980s triggered a storm of publications by scholars who coined the phrase 'hate speech' for the legal lexicon. Some of the offences had already been subject to legal or institutional penalties for harassment or vandalism. Several universities nevertheless adopted broad codes of conduct to penalise hateful expression. For two decades, however, the US Supreme Court had been marching in the opposite direction. It was interpreting the Constitution's First Amendment to prevent federal or state government from punishing speakers solely on grounds of the viewpoints they express.

Many regulations of speech are scarcely disputed. Most theorists on either side of the hate speech debate largely agree that speech cannot be so free as to trump all countervailing interests. The law obviously should not protect commercial fraud, or courtroom perjury, or, to recall Oliver W. Holmes's famous example, 'falsely shouting fire in a theatre and causing a panic.. ${ }^{\text {I }}$ More importantly, few of the leading opponents of bans would extend expressive rights so far as to protect hatred spoken in live, immediate, face-to-face encounters (as in stalking, harassment, or socalled 'fighting words' situations); or under circumstances of, for example, employment, or primary education, or general provision of goods and services; or immediate and specific solicitations to commit acts of hate-motivated violence or material damage (e.g. 'Hey Jack, go pick up that brick, and let's go kill that faggot over there!'), as opposed to wholly vague and openended appeals, say, to 'Overthrow the agents of capitalism!' (which would require us to ban much Marxist writing; see, e.g., Heinze, 2008, pp. I39-4I) or 'Behead all non-believers' (BBC News, 2006). The more difficult question is whether democracies, as many Western European states currently do, ought to penalise hateful opinions uttered within the sphere of public discourse -

* Many thanks to Thomas Brudholm and to an anonymous reviewer for their detailed comments.

I Schenck $v$. United States, 249 US 47 (I9I9), at p. 52. 
within contexts serving the open and general expression of individual viewpoints on matters of political, social, cultural or indeed purely personal concern.

\section{A new century}

A cardinal principle of US law since the I96os has been that speech must not be regulated solely on grounds that the speaker's worldview, or viewpoint, is in itself unacceptable or even dangerous. As James Weinstein explains (2009b, pp. 82-83):

'Content-based laws are ones in which the government seeks to regulate expression because of the message it conveys. Content-neutral regulations, in contrast, regulate speech for some reason unrelated to the message, such as the time, place, or manner of the speech. A law forbidding anyone from speaking about abortion is content-based; one prohibiting the use of loudspeakers in residential neighbourhoods after ro.oo pm would be content neutral. [...] The most "egregious" type of content regulation is viewpoint discrimination. Viewpoint discriminatory regulations ... are ones based on "the specific motivating ideology or the opinion or perspective of the speaker"'2

A ban, for example, on all discussion of abortion rights, either opposing or supporting them, would be content-based, entailing obvious problems of democratic legitimacy. But wide freedom granted to anti-abortionists, with little or none granted to pro-abortionists, would raise its own question of legitimacy. Speech then becomes free to the extent compatible with the state's view. Bans on hate speech within public discourse 3 grant freedom to one viewpoint while penalising the other. In Western Europe, hate speech bans, in their current form, have long been a fait accompli, largely as first responses to still recent histories of genocide and colonialism. In European legislatures and courtrooms, one individual's right to speak is routinely balanced alongside other citizens' claims to maintain their human dignity.

Europeans have sometimes contrasted their prudent weighing and balancing with an unfeeling America that elevates aggressive individualism over all other values. Well into the I99os, Western European jurists and scholars largely believed they could write off domestic US hate speech controversies as irrelevant to a continent achieving a consensus within the European Convention on Human Rights (ECHR) and international conventions. Democracies like Australia, Canada or New Zealand shunned the American model, joining the European approach. By the close of the twentieth century, the Western European approach seemed - almost everywhere outside the US - obvious. Little soul searching seemed necessary, except as to the minutiae of scope and implementation. Many Europeans saw American racism as confirmation that hate speech fans the flames of violence, while punishing it nurtures tolerance (see, e.g., Boyle, 200I). Rejecting the postI960s First Amendment trend, American advocates of bans agreed (see, e.g., Matsuda, Lawrence, Delgado and Crenshaw, I993). A European political and legal consensus deemed extreme speech an obvious object of routine legislative or judicial restrictions - no different from the weighing and balancing required in any routine regulatory context, as witnessed by the brief, if not altogether absent, discussions of bans in leading European civil liberties textbooks well into the I 990 (see, e.g., Lebreton, I999, pp. II I-22; Robert and Duffar I996, pp. 653-56; Fenwick, 2002, pp. 327-30).

2 Quoting Rosenberger v. Rector and Visitors of the University of Virginia, 5 I5 US 8I9 (I995), at p. 829. See also Weinstein (2009b, pp. 86-87, 9I).

3 On the concept of 'public discourse' as an essential realm of democratic legitimacy, see, e.g., Post (I 995, pp. 7, I34-77, 20II, pp. 483-84). 
A new century would shake that European consensus to the core. The attacks in the US of II September 200I were followed by the murder of Dutch filmmaker Theo van Gogh, the Danish cartoon controversy, French bans on burqas, Swiss bans on minarets, terrorist attacks in London, Madrid and Oslo, and the growth of mainstreamed far-right political parties. Settled assumptions about provocative expression suddenly came in for scrutiny. Many Europeans persevered with the earlier logic, demanding broad limits on hate speech (see, e.g., Grimm, 2009). Others began to challenge the consensus (see, e.g., Vaneigem, 2003; Wijnberg, 2008). As arguments for and against bans were revisited, closer trans-Atlantic comparisons became inevitable. Europe was suddenly flooded with conferences on hate speech. They were often themed in 'US versus Europe' terms. One gathering in 2007, at Cambridge University, entitled Extreme Speech and Democracy, was organised by Ivan Hare and James Weinstein. It assembled an international cast of scholars, representing a range of legal systems, philosophies and methods. The organisers edited the resulting anthology, of the same name, appearing in 2009, boasting over 30 chapters, and spanning more than 600 pages.

Three short years later, Michael Herz and Peter Molnar's The Content and Context of Hate Speech offers another such collection, similar in its aims and breadth, and offering new insights. As in Hare and Weinstein (2009), most scholars in Herz and Molnar retain a focus on Western democracies, but with notable exceptions. In a number of transcribed interviews included by Molnar, as well as in his own chapter, this Hungarian expert, the driving force behind the anthology, draws incisive comparisons to Central and Eastern Europe. We can ask whether that region's volatility requires rules different from those of Western democracies; but we are then left with the question: Different from what, from the Western European consensus, or from the American exception? Molnar dissents from the prevailing Eastern (and Western) European view. When admonished to the effect that free speech 'may be fine for wealthy Americans, but cannot work for a turbulent Eastern Europe', Molnar has long retorted that Eastern Europe, whose modern history is a chronicle of repression, needs candid speech to confront that vertiginous past.

Other contributions further remind us of debates outside the West. Andrei Richter's chapter, also examining post-Soviet regimes, shows how easily the humanist pretensions of hate speech bans are manipulated by non-democratic or weakly democratic states, not to protect vulnerable minorities, but to punish them for speaking out against the power of the dominant ethnic majorities. The anthology also offers inroads into non-Western societies in a chapter by Yared Legesse Mengistu, who sets the stage for exploring African contexts, through an analysis of recent Ethiopian and Rwandan histories. Kwame Anthony Appiah, in a chapter taking a more global approach, views seriously the impact of blasphemy on sincere religious believers, but rejects initiatives to adopt anti-blasphemy codes within international legal frameworks. Despite those inroads into nonWestern contexts, the core theoretical debates in Herz and Molnar largely retain the 'US versus the world', and more particularly the 'US versus Europe' tenor of many other publications. An overall European (again, largely understood to include non-European democracies that maintain hate speech bans) alternative stands as the theoretical counterpart to dominant US First Amendment doctrines.

Free speech scholarship in the US is old and it is mountainous. By the end of the last century, one might have wondered whether fundamentally new normative principles would still be surfacing, even if electronic technologies were expanding the arenas in which such principles are applied. In Europe, by contrast, free speech had, until the current century, never attracted greater scholarly interest than any other areas of civil or even social rights. Unsurprisingly, in trans-Atlantic exchanges, Americans have frequently offered highly self-contained analyses of free speech, as a theoretical sphere unto itself (as witnessed, in Weinstein's (2009b) analysis, by the full-blown lexicon of 'content', 'viewpoint', 'forum' and related concepts), while Europeans have largely referred to the broader principles of dignity, equality and rights-balancing that underpin European 
and international legal frameworks. Such trans-Atlantic exchanges spark stimuli at both ends. Scholars in the US, where the 1789 Bill of Rights has generated dignitarian rights only obliquely, e.g. through an arcane case-law on 'substantive due process', have had to ask whether experiences in other democracies suggest heretofore underappreciated limits to First Amendment principles. Europeans studying Holmes, Brandeis, Douglas or Black have found themselves rethinking the democratic legitimacy of government control over public discourse.

\section{Modelling democracy}

Herz and Molnar begin by surveying the climate in First Amendment circles, through an interview between Molnar and the Yale Law School free speech theorist Robert Post. In a string of law review articles dating back to the I980s, Post has developed his opposition to viewpoint-based regulations of public discourse, grounded in a theory of democratic legitimacy. Post's (2009) chapter in Hare and Weinstein reaches beyond his earlier American focus, but still looks askance at European interferences with individual freedom. In his interview with Molnar, Post renews his defences of the American approach, but now defers to Europeans' desire to retain bans. Despite the abstractuniversal, liberal legal subject that readily emerges from strong First Amendment defences of speech, Post now proclaims agnosticism about the superiority of American approaches for other democracies. 'It could be', he concedes, 'that participation in opinion formation in certain ways, in certain countries, in certain national contexts, destabilizes democracy rather than legitimizes it' (p. 25).

The reader may wonder how far that equivocation stretches. Post effectively (though not by name) rejects Ronald Dworkin's (2009, p. ix) extreme of a simplistic, one-size-fits-all model of democracy, but only by swinging to the opposite extreme: a political relativism leaving us clueless about why or when viewpoint-selective limits on speech become intolerable for democracies generally. For any given democracy, either majority or elite attitudes towards hate speech will generally prevail. But that observation only begs the question as to how we can critically evaluate the result. On the one hand, Post has long argued that neither majority nor elite opinion in themselves render speech restrictions legitimate. Citizens' democratic freedom of speech, on that view, is not a licence granted by government. It is a normative precondition for the establishment and ongoing credibility of government. 'TT]he right to freedom of speech is logically and sociologically dependent' not on majority or elite preferences, but rather 'on an anterior right to democratic participation' (p. 24). If, on the other hand, as Post now expressly avows, free speech might endanger some democracies, how are we to distinguish between those which can and those which cannot persuasively justify bans?

Post's open-ended pluralism ends up question-begging for a good number of democracies in which long-standing majority or elite preferences are being re-examined. His views on democracies other than the US break off the enquiry precisely where, for Europeans, it has just begun. It must surely be unsatisfactory for us to resolve questions of political legitimacy wholly through deference to majority or elite preferences. Criteria for democratic legitimacy must serve for us to evaluate majority or elite opinion, and not merely to recapitulate it. That critical process is not wholly subjective. It is built into our law. In Europe, the ECHR (regardless of our views about the Court's disposition of this or that particular problem or dispute - which has proved unsatisfying in several cases about free expression) 4 and its broader Council of Europe framework, represent nothing if not the proposition that deliberation about national democratic legitimacy can justly proceed at levels external to the nation's domestic deliberative sphere, indeed through recourse to higher-law principles.

4 For examples of frequently criticised ECHR judgments, see, e.g., Otto-Preminger-Institut v. Austria, ECtHR, Ser. A, No. 295-A [I994]; Wingrove v. The United Kingdom, Ser. A, I996-V, No. 23. 
Even for observers who (on, for example, more nationalist Rousseauvian, Hegelian or Schmittian models) reject any such external or quasi-external deliberative spheres, acts of normative political deliberation, even deliberation 'at home', inherently presuppose the pondering of solutions that may vary from majority or elite preferences, in turn presupposing the possibility of normative criteria conceptually external to those preferences. What we need, in a nutshell, is not to stop the hate speech debates with an acknowledgment that democracies outside the US may have different preferences. Rather, starting with that recognition, we must then proceed to the next step, by identifying principles for evaluating those reigning preferences. Which political principles should guide any given non-US democracy towards retaining well-established hate speech bans, and which principles would justify abolishing them? On what normative grounds ought Europeans to challenge their bans, as many now seek to do? What normative principles would justify the success of such challenges, beyond the unpredictability of changes in popular or elite attitudes?

While I certainly concur with Post's tacit rejection of Dworkin's extreme, i.e. of a simplistically universalist model of democracy and its requirements of free speech, I elsewhere reject Post's opposite extreme of mere deference to national preferences (Heinze, forthcoming 20I4). I advocate a view mediating between those poles. I propose a historically inflected concept of democracy, which I call a 'democratic-historicist' model. I identify within broader democratic theory a more limited model of the 'long-standing, stable and prosperous democracy' (hereafter 'LSPD'). That concept may appear vague on its face, but gains clarity through well-developed bodies of law governing states' available capacities and resources to enforce human rights. I argue that the LSPD, an essentially post-World War II phenomenon, offers a framework for evaluating the legitimacy of bans.

By long-standing, I mean a society that does not claim to be democratic merely because its citizens drop an occasional ballot in a box, but in which some significant portion of the voting population has been educated with basic attitudes of universal prerogatives of citizen participation, public political scrutiny, and reliable expectations of individual legal protections. The term 'long-standing' does not denote strictly chronological time, but a period during which general norms, practices and expectations of democratic participation have generalised within the citizen population. Such education does not occur overnight. It is nurtured over decades, from the youngest ages, and since World War II has been honed through progressive anti-discrimination policy. The US as a whole, for example, which includes the former segregationist states (with all that such formalised racism entails as to pervasive abrogation of any plausible principles of the rule of law), could not count as an LSPD much before the late I960s, in terms of legal reform taking both formal and practical effect, and despite a longer history of displaying, though geographically and demographically variable, substantial democratic character.

By stable, I refer to a democracy sufficiently able to police itself, according to independently (e.g. judicially) reviewable criteria, so that alternative means of combating intolerance and protecting its targets can be made available without the state having to impose viewpoint-selective restrictions on speech. Those alternatives include sufficient protections from violence or discrimination against vulnerable parties, and adequate provision of safety during such public events as political demonstrations, as well as viewpoint-neutral time, manner and place regulations on speech. By prosperous, I refer not to a utopia that has eliminated all political, economic or social injustices, but to a democracy sufficiently wealthy to maintain effective penalties against violence and discrimination, as well as non-punitive means of combating intolerance and protecting vulnerable individuals, while preserving viewpoint neutrality within public discourse. Such practices mean that controversial political or cultural events can proceed, with speakers, audiences and dissenters alike protected from violence, with no speakers silenced solely on grounds of their undesirable views.

In developing the LSPD paradigm, I take no position on its worthiness as a comprehensive system of politics. Broader defences of the liberal or capitalist elements of Western democracies have remained subject to a range of criticisms. Despite the assumption by many advocates of bans that 
such restrictions supply necessary responses to democracies' failures, I argue that no such conclusion follows either in theory, or in terms of practical action against injustice. By way of comparison, in Rien n'est sacré, tout peut se dire (2003), the veteren leftist Raoul Vaneigem, while challenging liberal rights regimes, vigorously opposes hate speech bans and other viewpoint-based restrictions within public discourse. That standpoint forms part of his project to overcome what he, in a Foucauldian vein, portrays as the illusory intellectual freedoms of liberal capitalist society, which in fact turn out to be intellectual homogenisation and therefore effective regimentation (see also Butler, I997). That position prompts Vaneigem to urge the abolition of punitive restraints on public discourse, not only within some future society, but immediately, under existing liberal regimes. For Vaneigem's post-Marxism, there may be endless problems with liberal capitalist democracy, but citizens' prerogatives of free speech is not one of them, and, to the contrary, offers a weapon against liberalism's excesses. Meanwhile, at the opposite pole of the debate, not all advocates of bans have been progressives. On a longer historical timeline, the age-old practice of viewpoint-selective bans on speech has overwhelmingly been one of repression of minority and dissenting voices.

\section{Narrowing the question}

Recourse to the LSPD concept, to refine our understandings about divergent democratic contexts, warrants further refinements, without which the debate readily falls prey to confusion. My focus is on the sphere of public discourse (hereafter PD), on the understanding that most serious opponents of bans do not challenge such things as protections from stalking, 'fighting words' or workplace discrimination (although a libertarian faction refuses even to concede this much), but only viewpoint-based limits within the sphere of public discussion. A series of abbreviations may help to identify the dispositive level of debate:

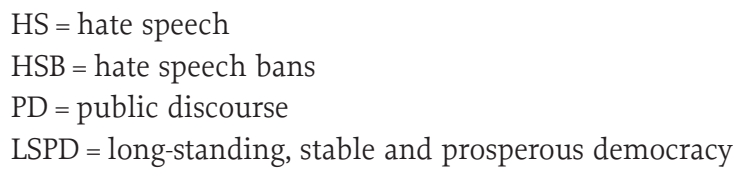

The aggregations will appear cumbersome, though less so, I hope, than their long forms. Hence:

HS-PD = hate speech in public discourse

HSB-PD = hate speech bans in public discourse

HS-PD-LSPD = hate speech in the public discourse of long-standing, stable and prosperous democracies

HSB-PD-LSPD = hate speech bans in the public discourse of long-standing, stable and prosperous democracies

The controversy of focal interest, then, concerns HSB-PD-LSPD: Are they justified? We can confidently reply 'No', as the question now contains that series of necessary refinements which looser formulations of the issue have lacked. In a further effort to economise, I propose the admittedly imperfect term prohibitionists to avoid the more cumbersome 'advocates of HSB-PD', and oppositionists for 'opponents of HSB-PD'.

Hate speech debates have focused too narrowly on outmoded criminal-law paradigms of law as a sheer regime of punitive sanctions: either the state punishes hate speakers, or it remains indifferently neutral. Post rightly rejects that false dichotomy. He recalls that nations, including the US, can and do adopt vigorous anti-hate and anti-discrimination policies without having to punish speakers solely on grounds that their views dissent from that message. '[I]t is important to avoid a picture in which 
the state either acts in an aggressive and intolerant way or is paralyzed and cannot act at all' (p. 22). Post explains that, under America's prevailing First Amendment jurisprudence, 'even though we prevent the state from regulating public discourse in the name of a community norm, we nevertheless freely allow the state to participate within public discourse as a speaker' (p. 22), that is, as long as it uses means, such as public schools or public interest campaigns, that promote tolerance without punishing those whose ideas fail to conform. 'The state', Post emphasises, 'is a frequent, powerful and loud participant in public discourse' (p. 22). Post continues:

'as a general matter, the American state is far from neutral. The American state takes substantive positions all the time. It affirms civil rights, equality, toleration, and so forth. Consider our regulations of workplace actions and speech. [...] Consider the rules and regulations that the American state imposes on the army, on government institutions, on contractors, and so on. No one should confuse the American state with a neutral state.' (p. 26)

That model of what I call an 'active' (as opposed to libertarians' ideal of a morally 'neutral' or 'night watchman') democracy reflects the LSPD which remains vigilant and interventionist through comprehensive public, civic, educational, employment and commercial policies on intolerance and discrimination, without having to punish individual citizens whose views fail to reflect those values. Such a model is reflected also in Molnar's chapter. These scholars signal a shift in focus away from conventionally punitive, criminal-law paradigms, towards the active state's role in promoting tolerance and 'counter-speech', through measures to empower traditionally vulnerable individuals and groups (see also, e.g., Brettschneider, 2012).

The exchange with Post finds a further companion in Molnar's interview with Nadine Strossen, who, having served from I99I through to 2008 as President of the American Civil Liberties Union, has long opposed viewpoint-based restrictions on expression. If Post focuses on the theoretical foundations of democratic citizenship, Strossen emphasises pragmatics and public policy. '[I]t's so easy for politicians to regulate expression,' Strossen warns, 'because it doesn't cost anything. They don't have to raise taxes to censor speech. [...] In response to unacceptable levels of violence in society, what is targeted in [the US]? Violence in the media. We have too few serious efforts to regulate handguns' (p. 38I). Echoing the 'active democracy' model, Strossen maintains that 'a far more powerful and effective message is expressed' against intolerance through measures such as anti-discrimination and civil rights laws (p. 39I). In a further interview with Molnar, the African-American civil rights lawyer Theodore Shaw recalls how legally permitted hate speech has helped American rights advocates to gather valuable evidence of motive in criminal cases (pp. 399-400), in contrast to the less careless approaches likely to be taken by racist criminals who, under the shadow of bans, learn to cover their tracks and code their messages. Strossen echoes that concern for social life generally. She quotes the Harvard African-American studies scholar Henry Louis Gates, Jr., who warns that it is a 'mistake' for us 'to spend more time worrying about speech codes than about coded speech' (p. 383).

\section{Some consequentialist approaches}

Arch-opposite to Post and Strossen, the British House of Lords member Bhikhu Parekh retains familiar defences of HSB-PD. He hails the 'high value' of speech, calling 'free speech . . . an important value, [but] not the only one' (p. 43). Both deontological and consequentialist approaches have shaped the hate speech debate, and Parekh cites both for supporting bans: 'Hate speech', Parekh claims, 'is objectionable for both intrinsic and instrumental reasons' (p. 44). On both sides of the debate, however, writers at times make ostensibly consequentialist, i.e. ostensibly empirical, arguments about the dangers of bans, while in fact, like Parekh, offering only speculation about further material harms to persons that hate speech might cause. I elsewhere use the phrase 'rhetorical 
consequentialism' to classify some prohibitionists' tendencies to make ostensibly empirical claims about hateful words leading to violence (or about HSB-PD-LSPD promoting greater tolerance), while failing to present empirical evidence supporting those claims, except with reference to weak or unstable democracies, such as Germany's Weimar Republic or the disintegrating Yugoslavia of the I990s. While the overall social concerns are certainly understandable, my aim in identifying rhetorical consequentialism is to suggest that it is in fact deontological claims which are being presented under the guise of empirical argument, i.e. that HSB-PD are advocated not because, but regardless of, demonstrable social effects (Heinze, 20I4 forthcoming).

The PD-LSPD concept serves to distinguish most Western democracies from more volatile counterparts, such as India or Israel. Parekh praises both of those states for their bans. Like many prohibitionists, he fails to distinguish adequately between, on the one hand, states with such mass turbulence, and, on the other hand, LSPDs like France, Germany or Northern European democracies, whose declared need for HSB-PD cannot be based on degrees of sociopolitical instability comparable to those of India or Israel. Elsewhere, even leaving aside evidence such as Richter's of hate speech bans being used against vulnerable groups, I have cited studies of European far right activity which suggest that HSB-PD-LSPD may have effects very different from any benefits they are thought to bring. Bans have actively tutored hate speakers in techniques of legal evasion and purely cosmetic mainstreaming, rendering their messages not less dangerous, but rather more insidious (Heinze, 2014 forthcoming). While some oppositionists court rebukes for assuming universalist concepts of democracy, Parekh and other prohibitionists risk the converse mistake. They presuppose a one-sizefits-all model of democracies' dangers. They assume that risks identifiable in some, usually young, unstable or impoverished democracies, are therefore problems necessarily inherent within all democracies: if hate speech led to genocide in what was a constitutionally democratic Weimar Republic or Rwanda, then ipso facto, the logic runs, the same danger haunts Finland or Luxembourg.

Such reductive assumptions about democracy take little notice of historical shifts that have distinguished LSPDs, in education, civic life, public attitudes and the media. In an interview between Molnar and the London-based writer Kenan Malik, many of Parekh's claims about the virtues of British bans face forceful challenges. Malik doubts both the aims and the efficacy of bans. 'Hate speech restriction', Malik argues, 'is a means not of tackling bigotry but of rebranding certain, often obnoxious, ideas or arguments as immoral. It is a way of making certain ideas illegitimate without bothering politically to challenge them' (p. 8I, original emphasis). Parekh celebrates arrests in Britain for 'incitement to racial hatred' (pp. 53-54) (which, lest we forget, denotes punishing the crime of possibly inducing some otherwise unidentified observer to experience and act upon an unacceptable emotion). Parekh, like other leading prohibitionists, never enquires into the success of those laws' declared aims, i.e. of contributing to any discernible reduction in racism. Malik resists abstract formalisms, opting for what theorists would recognise as a legal-realist insight. He examines bans not only in terms of their ideally formulated goals, but also in terms of the everyday human society within which those goals can be seen to succeed or fail. 'In I965,' he recalls, 'Britain prohibited incitement to racial hatred as part of its Race Relations Act. The following decade was probably the most racist in British history' (p. 84).

Malik lays no claim to explaining that contradiction through material causation. He does not assert that the 1965 law directly triggered increased racism. Nor, however, can any such burden of persuasion rest with Malik to challenge HSB-PD-LSPD by showing such material causation. One of democracy's normative presumptions favours citizens' prerogatives to speak, until such time as states can demonstrate that such freedom causes some actual or likely, or at least more than speculative, detriment. 5 Prohibitionists have plausibly, and rightly, identified such harms within

5 As to whether dignitarian claims can carry that burden, independently of any such empirical findings, see Heinze (2014, forthcoming). 
emerging, weak or unstable democracies. Like Parekh, however, they cite no statistical evidence of free speech causing any such harms within LSPDs, despite the sweeping proliferation of such speech, particularly since the explosion in Internet use since the I990s. Even if Malik does not seek to show that the bans specifically contributed to the rise in racism, his position challenges the bans' declared benefits.

Let us recall some epistemological truisms: 'history does not disclose its alternatives'; and 'it is impossible to prove a negative'; and 'absence of evidence is not evidence of absence'. Some prohibitionists therefore insist that bans cannot be shown not to work, since intolerance might have been worse in Europe without bans. It is unsettling to imagine such reasoning applied to other fundamental elements of citizenship (after all, absence of evidence that torture usually works is not evidence that it never works). States' traditional willingness to accept rhetorically consequentialist, i.e. formally causal yet, as to LSPDs, wholly speculative, justifications for limiting one of democracy's core legitimating conditions, raises questions of democratic legitimacy that are still overlooked within European political, legal and scholarly circles.

\section{Some deontological approaches}

Herz and Molnar note that their anthology draws largely from colloquia held in New York in 20Io, at Yeshiva University's Benjamin Cardozo Law School. One of the volume's curious features is that several contributors comment, with a hint of anxiety, on a paper that was presented and included in the volume, by Julie Suk. Discussing French bans on Holocaust denial, Suk appears to have caused a stir. She presents a seemingly alarmed American audience with arguments that, in several European states, have long seemed commonplace. In France, as elsewhere on the continent, the anti-negationist loi Gayssot provoked fairly little controversy at home after its adoption, except during the occasional high-profile criminal prosecutions brought against such Holocaust deniers as Robert Faurisson or Roger Garaudy. Aside from such prominent cases, recent French controversies are often not about whether the bans should be abolished, but whether they should be extended, beyond the Shoah, to cover denials of other atrocities, such as the Turkish genocide of ethnic Armenians.

Confronted with claims such as Post's, that free speech constitutes a legitimating condition of democracy, Suk counters with a rival deontological, rather than consequentialist, theory of political legitimacy:

'In France, by criminalizing Holocaust denial, the state makes clear that racism has no place in collective self-determination. This exclusion enhances, rather than undermines, the state's legitimacy, because the state cannot govern legitimately unless it makes a strong, clear break with a past racist regime.' (p. I45)

Suk succeeds in articulating one version of what has become - largely because of the aforementioned failures to substantiate consequentialist claims - the dominant prohibitionist theory, now commonly recognised under the heading of dignitarianism, as echoed also on the deontological side of Parekh's arguments. 'In France,' writes Suk, 'as in Germany and other European nations, criminal law has played a critical role in enabling the state and the society to face their collective responsibility for the Holocaust' (p. 149) - regardless, we might extrapolate, of whether that duty takes the form of punishing Holocaust denial, or of punishing at least the most extreme expressions of racism, antisemitism and, as the case may be, other kinds of intolerance. 'French law', Suk continues, 'treats the manifestations of racism as an injury to the entire polity and to the state rather than as individual injuries with individual victims' (p. I62). 
On Parekh's, Suk's, and other prohibitionists' claims, expressive participation in public discourse stands as a cornerstone of democracy, but only as weighed against each citizen's human dignity. If a general presumption of free speech secures that former cornerstone, then HSB-PD, on the dignitarian view, secure the latter. That dignitarian approach triumphs also in Michel Rosenfeld's chapter. Comparing the constitutional regimes of various Western democracies, Rosenfeld concludes, not based on evidence of effect, but on grounds of ethical principle, that 'the American way seems definitely less appealing than its alternatives' (p. 288). Having mounted a peremptorily deontological defence of bans, Suk's final paragraph, almost as a footnote, adds the consequentialist caveat that the French have not necessarily 'done a better job at achieving racial equality' (p. I63). To say the least! It is unfortunate that Suk fails to examine that impeachment of causal foundations for HSB-PD. If an LSPD can adduce no serious evidence for the effectiveness of HSB-PD, are those ideals to be credited as uncritically as Suk's chapter would have us do?

As Strossen has long maintained within the US context, and as evidence from Western Europe suggests, bans may strengthen hate groups' resolve and sense of mission by confirming their propagated self-image about elite control and political exclusion. German bans have encouraged myriad forms of undercover, underground activity, turning those groups not, as prohibitionists frequently promise, into depleted entities, but into vibrant, parallel societies. German neo-Nazis, like other far-right groups, have come to relish the ease with which they learn to flaunt bans, constantly honing their ability to brush up against the law, while falling just short of an ever-shifting illegality. From that legal-realist perspective, bans remain a questionable means indeed of vindicating the target group's dignity. Such a status quo leaves Germany, France and much of continental Europe with anything but that 'strong, clear break' with a racist past, which Suk and others employing such formalist reasoning deem germane either to democratic legitimacy or to human dignity.

In Moderne Nazis: Die neuen Rechten und der Aufstieg der NPD (2006), Toralf Staud shows how bans on neo-Nazi political parties in the early I99os correlated to increased membership of the far-right German National Democratic Party (NPD), by strengthening the party's self-propagated image of martyrdom. Less educated or socially outcast individuals, often easy prey, might have been frightened by franker imagery, but feel assuaged by messages tempered to comply with bans, sounding sympathetic and down to earth. The NPD has learned to promote a mainstream image through coded speech, an effect strongly echoed in the public presentations of far-right political parties elsewhere in Europe. One substitution for the banned 'Blood and Honour' (Blut und Ehre) simply became 'Glory and Honour' (Ruhm und Ehre). The swastika has sometimes been replaced by a Nazi-era triangular figure (das Gaudreieck). The Hitler greeting has made way for the 'Kühnen greeting', named after the post-war neo-Nazi leader Michael Kühnen, merely replacing the flat outstretched hand with three extended fingers. Far from dignifying victims of hatred, such 'cat-and-mouse games' (Staud, 2006, p. I74; cf. Schrank, 2006, pp. 20-22, 2628; Röpke and Speit, 2005, pp. I5, 23-24, 37, 44) make a farce of them.

German and European jurists have long remained indifferent to these effects of bans, in part because schools of legal realism have traditionally held a weaker foothold on the continent. Meanwhile, US-based prohibitionists like Delgado and Matsuda announce their confidence in foreign bans, yet their research shows neither a trace of evidence about, nor indeed any interest in, those bans' effects. A number of observers have pointed out that the US made its greatest strides in combating racism in and after the I96os, precisely the era in which its protections of speech, and rejections of bans, had moved into its strongest phase. Meanwhile, in Germany and France, strong enforcement of HSB-PD has accompanied record post-war levels of intolerance.

In his comprehensive monograph La négation du génocide nazi: liberté d'expression ou crime raciste? (2003), Martin Imbleau, like Suk, defends French penalties for Holocaust denial, yet equally observes how linguistic manipulations serve to mainstream the superficial expression of intolerance (pp. I77, I $83-84$ ). He, too, fails to ask whether those manipulations emerge precisely from the need to avoid falling foul of HSB-PD. Imbleau recognises 'taboos' surrounding Nazism among the stimuli that spur 
Holocaust deniers. Remarkably, however, in another all too typical prohibitionist move, he makes no attempt to explain how entrenching and consecrating those selfsame taboos, elevating our response from moral outrage to legally binding penalty, will diminish the incentive. Imbleau, along Suk's overall lines, condemns Jean-Marie LePen's concocted image as a free-speech martyr, yet fails to notice how it is precisely the penalties for speech which allow LePen to promote that image. Imbleau warns against the dangers of Holocaust negationism disseminated through the media attention lavished on antisemites like Faurisson. He fails to observe, however, that it is precisely the French ban, as with high-profile prosecutions of Holocaust deniers in Austria, Germany and elsewhere, which triggers the media hype. Holocaust deniers in the US rarely enjoy the celebrity their counterparts have won in Austria, Germany or France, precisely because US law, and therefore the US media, mostly ignore them. That consequentialist reality check steers us back to the heart of dignitarians' deontological claims. Questions arise as to how any victim's dignity is being preserved if bans, far from foiling hate groups, are teaching them how to mock and scorn vulnerable targets within the bounds of law.

An anonymous reviewer of the present review essay warns:

'empirical claims are frequently made for and against the different legal approaches ... but are rarely based upon robust empirical evidence. [...] I am convinced by [Heinze's] argument that [empirical] evidence is difficult to come by, is often of poor quality, sometimes poorly presented, and is always used for political and tactical purposes. But the strength of this argument seems to be deflated when [Heinze] engages in the very approach being criticised.' 6

Note, however, that prohibitionist and oppositionist consequentialisms assume, respectively, different kinds of causation chains. Prohibitionists assume far-reaching sociopsychological effects of HS-PD. That view seems contradicted not only by the fact that any such effects appear no stronger overall in the LSPDs of Western Europe, which have long maintained HSB-PD, than in the US, which has rejected them, but also by the fact that they appear no stronger in LSPDs with broad bans than those with narrow ones. The evidence I would cite, by contrast, about bans' provocative effects on hate groups assumes a narrower empirical field. It seeks no speculation on pervasive and ineffable social effects diffused throughout society as a whole. It identifies only the apparent responses of hate groups to the precise texts and immediate implementation of HSB-PD. Prominent hate groups have sequentially adjusted and re-adjusted their speech as bans are passed, enforced or amended, with the conspicuous aim of frustrating law enforcement. The advantage of much American intolerance (of course, not all of it) is its crudeness, because no legal penalties prompt speakers to mask it. Western European hate speech bans, by contrast, have educated extremists (not all of them, but certainly those who are most efficiently mobilised, and who are therefore, on prohibitionists' own reasoning, the most dangerous) in the methods of Orwellian newspeak, as copious specimens of far-right propaganda have long illustrated (see, e.g., current websites of the British National Party, ${ }^{7}$ English Defence League, ${ }^{8}$ Freiheitliche Partei Österreichs, ${ }^{9}$ Front National, ${ }^{\text {Io }}$ Nationaldemokratische Partei Deutschlands, ${ }^{\text {II }}$ Nederlandse Volks-Unie, ${ }^{\text {I2 }}$ Vlaams Belang ${ }^{13}$.

6 On file with the author.

7 British National Party <https://www.bnp.org.uk/〉.

8 English Defence League 〈http://englishdefenceleague.org/〉.

9 Freiheitliche Partei Österreichs 〈http://www.fpoe.at/〉.

Io Front National <http://www.frontnational.com/ . 
Readers favourable to Molnar's view may object that my replies to Parekh or Suk serve not to overstate but to understate the oppositionist thesis. My paradigm of LSPDs, which I call 'democratic-historicist', aims to mediate between Dworkin's one-size-fits-all model of democracy and Post's abdication of broader democratic theory, his democratic relativism. The LSPD model serves to distinguish democracies, such as the US, France, Britain or Germany, that now lack any basis in democratic legitimacy for suppressing speech on viewpoint-based grounds, from more volatile democracies, like India or Israel. For Molnar, by contrast, free speech must not be a luxury reserved for a small coterie of comfortable democracies. Free speech, on his view, is what weak democracies need in order to strengthen. Molnar's supporters may fear that the quasi-autocratic governments still dominating many emerging democracies could cite something like inadequate fulfilment of one or more of the three LSPD criteria precisely for the purposes of maintaining HSB-PD. Bans, then, as Richter warns, simply become Putinesque tools for suppressing any expression that inconveniences persons in power.

The LSPD model does run that risk. But autocratic governments intent upon manipulating law easily find ways to do so, and normative principles to justify such abuse, with or without HSB-PD. In January 2013, Russian authorities wished to punish a man for publicly kissing his boyfriend and, apparently lacking any other law under which to do so, convicted him of 'hooliganism' (Mirovalev, 2013). The LSPD paradigm by no means requires states falling below its threshold to adopt HSB-PD. It suggests only that non-LSPDs, under some circumstances, may have democratically legitimate reasons to do so, if only temporarily. Such cases do not prevent us from identifying bans as ultimately incompatible with democratic legitimacy, in the sense that bans ought to be removed once it is feasible to do so. In other words, HSB-PD must never be deemed, as dignitarian prohibitionists argue, a democratic ideal. If HSB-PD are justified, as might be argued for such states as India or Israel, it can only be because bans represent a democratic defect, like any number of defects which democracies must often confront under less than ideal circumstances. Herz and Molnar also include a final published essay by the prominent First Amendment scholar C. Edwin Baker. Completed just before his untimely death, Baker's chapter revises a piece he had earlier published in Hare and Weinstein (2009). Baker counts among the stalwarts of post-Warren Court vigilance. He brands himself an advocate of almost absolute protection of free speech' (p. 57). His approach nevertheless differs from those of Dworkin, Post or Weinstein. Their theses draw chiefly on principles of democratic legitimacy secured through citizens' access to public discourse. Baker refuses to derive prerogatives of speech from any such prior or 'pre-legal' assumptions about political legitimacy. Baker's 'absolutism' rests upon a personhood or autonomy theory, i.e. a view of expression as primordially constitutive of the human being, independent of social or political contexts. We can certainly observe that, Aristotle having defined the human being as, constitutively, the rational and the political animal, there remains something compelling about Baker's view that expression is not like other human activities. We might say that Baker identifies semiotic complexity and polysemic texture as delineating the human, such that our humanity becomes diminished if not erased when expression, however trivial or repulsive, is coercively silenced to achieve collective aims.

If, as Post warns, such a view of autonomy remains 'too vague and broad-gauged' (p. 24) to furnish unambiguous regulatory guidelines, another problem, as with Dworkin's, lies with Baker's unabashed liberal universalism. It has long been thought questionable to extrapolate from the admittedly compelling description of humans as inherently communicative, to any inherently

I I Nationaldemokratische Partei Deutschlands 〈http://www.npd.de/〉.

I2 Nederlandse Volks-Unie 〈http://www.nvu.info/〉.

I3 Vlaams Belang 〈http://www.vlaamsbelang.org/>. 
prescriptive right, which would have gone largely ignored throughout almost the whole of human history and culture, seemingly wedded to a rather recent, and Western, post-Enlightenment tradition. Baker never ponders such shortcomings in any historical or ethnographic way. He hopes instead, much as neo-natural law theorists commonly do, for intuitive agreement with his position.

Another more pragmatic point inevitably surfaces as troublesome, though perhaps not fatal, for Baker's 'absolutism'. As we are reminded in a chapter by Arthur Jacobson and Bernhard Schlink, perennial, generally lawful (even under the US First Amendment) and largely uncontroversial restrictions on speech remain manifold. Such limitations emerge in countless everyday situations other than fully-fledged public fora, such as education, employment or commerce (and even public fora are subject to so-called, albeit officially viewpoint-neutral, 'time, manner and place restrictions'). The number and variety of such limited speech contexts must be taken into account, and, as Stanley Fish has noted (I994, pp. I02-19), certainly leave questions about how much free speech 'absolutism' can survive. Jacobson and Schlink argue that the US does, to a large degree, 'restrain hate speech just like everyone else, but in a different ... limited and backhanded way' (p. 2I8). If Baker and other First Amendment loyalists can generally draw plausible distinctions between speech which does and which does not require 'absolute' protection, the distances they must travel to draw such lines may still leave observers doubtful about how 'absolute' free speech can ultimately be.

Adding brio into the anthology is a skirmish between Jeremy Waldron and Ronald Dworkin. Herz and Molnar appears in the same year as The Harm in Hate Speech, in which Waldron more fully explains his support for HSB-PD. Waldron's contribution in Herz and Molnar is a gauntlet thrown down to Dworkin's anti-ban legitimacy theory. Dworkin parries with the patience of a three-page riposte, which turns in part on an e-mail that, we are told, had passed between the two. Dworkin defends the earlier position that he had set forth in the Foreword he supplies to Hare and Weinstein's volume; and Waldron pursues a view outlined more fully in his monograph. The reader interested in these men's approaches will do better to consult their other writings on free speech first, returning to this debate after their general statements are clear.

\section{A liberal oppositionism?}

The word 'Harm' in the title of Waldron's concise and readable 2012 monograph holds a key to his approach. Traditional liberalism since Mill's (I982) On Liberty has insisted that some 'harm', some damage beyond sheer offence, must be shown if individual freedoms, particularly free speech, are to be abridged. Generations of European politicians and jurists have insisted on the material harms of physical violence directly incited by HS-PD. In the immediate aftermath of the Holocaust, a post-war era also marked by new attention to racism and colonialism, that causation seemed self-evident.

Of course, LSPDs are not merely formal, constitutional democracies. After World War II, they began to educate whole populations, from the youngest ages and now into the third or fourth generation, in values of autonomous citizenship and democratic process. That mission is not always successful nor ever completed, yet knows no historical precedent on such a wide demographic scale. Again, as opposed to the Weimar Republic, the former post-socialist Yugoslavia or Rwanda, any demonstrable causation between violent speech and violent conduct within LSPDs - despite our inundation in extreme speech and imagery, particularly since the Internet revolution of the I990s - has proved elusive to prohibitionists. Many prohibitionist writers ignore the aforementioned evidence that, within LSPDs, bans are not only having no effect but may be provoking the opposite of their intended effects. Waldron has good reason to avoid making at least some of the consequentialist-empiricist mistakes of other writers, hence his focus on a deontological-dignitarian defence of bans. To be sure, he never draws that consequentialist- 
deontological distinction expressly. Much of his discussion still strongly insists on ascertainably harmful, albeit never empirically substantiated, effects of HS-PD-LSPD. At the same time, he makes clear that the book's title refers principally to harm caused to human dignity, a concept indeed jurisprudentially grounded in some countries, famously post-war Germany, although — as with Baker's personhood or autonomy theory - one might question how persuasively the concept has been theorised.

Writing apparently for a US readership, Waldron tries his own hand at the 'US versus the world' paradigm, in his quest to challenge the prevailing First Amendment jurisprudence. ${ }^{\mathrm{I} 4}$ Having assiduously defended bans, Waldron rues hostile responses his views have provoked (p. Io). He insists on his 'modest intention' neither to advocate bans nor 'to persuade' us of their 'wisdom and legitimacy' (p. II; see also Waldron and Weinstein, 20I2, minute 48:04-48:59), but instead merely to help us to 'understand' them (p. I2). One could certainly challenge that distinguo, given the substance of Waldron's arguments. Nowhere does it alter his decisive points, which unequivocally praise the superiority of pro-ban over anti-ban positions for every legal regime he discusses with any hesitation reserved, as for other prohibitionists, only for the usual questions of scope or implementation.

After raising initial doubt about familiar defences of free speech (pp. 18-33), Waldron inaugurates his defence of bans by attempting to re-found dignitarianism within a Rawlsian framework (pp. 65-7I). That step certainly has strategic appeal. The first wave of US-based prohibitionist scholarship, in the I980s and I990s, had germinated as part of far-reaching condemnations of American law, particularly within the critical race theory of such writers as Richard Delgado, Mari Matsuda and Charles Lawrence, and the radical feminism of Catharine MacKinnon or Andrea Dworkin. Again, continental Europeans' traditional acceptance of bans meant that they rarely felt the need to underpin HSB-PD with more than cursory theoretical grounding or ostensibly self-evident historical references. Waldron's invocation of Rawls apparently seeks, on the one hand, a more reliable theoretical foundation than is to be found in other sources, while, on the other hand, avoiding broad commitments to his purportedly radical predecessors, with whom Waldron's otherwise mainstream approaches to law share little common cause.

To be sure, the radicalism of those other US-based writers need not be overstated. Their specific writings on hate speech seek to reform existing law. Since Waldron, too, avoids any empirically rigorous demonstration of acts of violence or discrimination directly caused by HS-PD-LSPD, he must, insofar as he is theorising within that political and legal framework, substantiate a deontological, dignitarian trump over the First Amendment's bar to viewpoint discrimination. Hence Rawls's strategic attraction for Waldron's project. Waldron seeks to present HSB-PD as consistent with, even required by, a rights-based democracy, not as antagonistic to it, as bans are largely viewed within a Millian liberal tradition.

At the outset, Waldron concedes that Rawls states no known position on bans; that Rawls's writings remain, at best, ambiguous in their implications for HS-PD, and, at worst, hostile to bans (pp. 69-70, 249-50). There is some reason to think that the aim of the early Rawls's 'original position' is to postulate an arena in which all general viewpoints, however odious, must be fair game before we can then imagine as legitimately constituted the society that can come to some

I4 As a doctrinal matter, Waldron in particular advocates a revisiting of Beauharnais v. Illinois, 343 US 250 (I952) (pp. I 2, 27-28, 40-4I, 47-52, 57, 6I-54), in which the US Supreme Court upheld a prosecution for group defamation. While that plea is not uncommon among US-based prohibitionists, Waldron attempts to revive Beauharnais by challenging interpretations of the I964 case of New York Times v. Sullivan, 376 US 254 (I964), but omits discussion of the US Supreme Court's views on viewpoint discrimination, as set forth, for example, in such cases as R.A.V. v. St Paul 505 US 377 (I992) or Virginia v. Black 538 US 343 (2003). Cf., e.g., Weinstein (2009b, pp. 84-88). 
consensus about the best values of democracy, fairness and tolerance, and the more specific laws and policies that will flow from them. It is difficult to imagine individuals behind Rawls's 'veil of ignorance' precluding the speech of citizens before they have had any chance to know what it is, or how respectful or disrespectful it may be. Having said that, the 'veil of ignorance' perspective often appears so artificial on such particular policy questions as to leave the matter murky. Nor do Rawls's later views on 'political liberalism' shed specific light on the hate speech debate. Waldron does not discuss Rawls's A Theory of Justice (I999), despite Rawls's own view that his political philosophy forms an overall continuity.

Given what is at best uncertainty about a Rawlsian stand on hate speech, our first query to Waldron might be: Why even choose a Rawlsian model? Given the dignitarian priority, why not adopt, for example, a communitarian model, as formulated by MacIntyre or Taylor? The problem with those models is that they stray back towards more comprehensive critiques of those individual rights regimes within which Waldron wishes to identify a dignitarian component. Waldron in effect stakes out an argumentum a fortiori. If he can show that even the assumptions of a deeply liberal, rights-based regime like Rawls's must nevertheless entail a dignitarian foundation, requiring some role for HSB-PD, then he need not tread the thornier terrain of broader philosophical battles between liberalism and communitarianism or schools critical of the legal mainstream. Waldron wants dignitarianism not as a challenge to, but as a cornerstone of, rightsbased liberalism. If he can conquer liberals, he can conquer most others.

The real question is not whether LSPDs are inherently hostile to dignitarian principles. Dignitarianism is crucial in turning the elements required for a society to be democratic at all, or democracy's 'minimal conditions', into the elements required for that society to be a good democracy, or democracy's 'optimising conditions'. That is why I, and most other oppositionists, favour rafts of more legitimate, and more effective, measures for 'active' democracies to promote tolerance without the further step of punishing citizens solely for the expression, within public discourse, of intolerant ideas. That is also why I would criticise both prohibitionists and oppositionists for having too often theorised the relationship between speech and democracy in the simplistically criminal law terms of law as a sheer regime of penalties —a model we might be expected to shake off in our first year of law school. Disagreeing as to whether HS-PD is an appropriate object of coercive control, both sides have focused too narrowly on classical paradigms of the 'night watchman' state, overlooking the morally active and peremptory role of a democracy as an affirmative and comprehensive speaker, far from neutral. Waldron's book, too, largely assumes that antiquated criminal-law paradigm (regardless of any views of law he may embrace in his other writings). Condemning oppositionists for rejecting specifically criminal penalties, Waldron reverts to the straw-man of extrapolating that, for oppositionists, intolerance is therefore 'no concern of the law' (p. 3).

As noted earlier, nothing could more distort the image of the 'active', interventionist state embraced by several oppositionist writers (although, admittedly, some on the libertarian fringe would dismantle even anti-discrimination law or public education). Waldron collapses all relevant law concerning intolerance into that which 'a good society should use its legislative apparatus to suppress or disown' through viewpoint-punitive rules (p. 3, emphasis added). Waldron's reference to a state that also provides 'public education' (p. 79) may well hint in a direction beyond the criminal law paradigm. But that concept of the active democracy, pursuing the aforementioned non-punitive policies, otherwise remains so peripheral in the book as to be invisible. As Baker reminds us (2009, p. I49):

'the debate is not between idealistic but uncaring "liberal" defenders of free speech and fierce opponents of the worst forms of racism. Rather the pragmatic debate is about different empirical predictions concerning the most effective strategy for opposing racism.' 
That kind of reductionism leads Waldron, like other prohibitionists, to exaggerate the EuroAmerican schism. 'It is not clear to me', he argues with a somewhat nebulous double negative, 'that the Europeans are mistaken when they say that a liberal democracy must take affirmative responsibility for protecting the atmosphere of mutual respect against certain forms of vicious attack' (p. 30; cf. p. I02). Does 'the Europeans are not clearly mistaken' mean that they are clearly right? If not, then what point is being made, aside from the commonplace that controversial issues can be argued one way or the other? As Waldron cites no difference between the 'affirmative responsibility' taken by Europeans and Americans aside from the punitive HSB-PD (with Americans largely having led the way in many of those non-viewpoint-punitive respects), 'affirmative' in that statement can mean only 'through viewpoint-punitive measures'. By 'vicious attack', moreover, Waldron can mean only 'vicious verbal attack within general public discourse', i.e. not live, face-to-face, 'fighting words' encounters, nor physical attacks, threats, harassment or traditional libel, since he knows that they can all be punished, often harshly, in the US.

Leaving aside questions as to how effectively the views of 'the Europeans' are reflected in their black-letter laws, only the most collapsed Austinianism can so straightforwardly equate 'affirmative' with 'punitive' duties. Decades after the first writings on hate speech appeared, prohibitionists such as Waldron still perpetuate the myth that oppositionists believe victims 'who detest hate speech should just learn to live with it' (p. 3; cf. pp. $32-33$ ), ${ }^{15}$ as if the state is barred from taking a broad array of coercive, albeit not viewpoint-punitive, steps. The state, after all, can coerce parents to ensure their children's schooling within a curriculum that includes compulsory reference to tolerance and pluralism. The fault lies in part with those oppositionists who, more out of convention or carelessness than conviction (since few of them have questioned the role of the state as active speaker and actor against intolerance), have focused their discussions on punitive models. That overstated view of US neutrality further contributes to a misleading transAtlantic comparison (pp. 8-I4, 29-3I), conjuring up an image of a quasi-Nozickian America that most of the leading US oppositionists do not advocate. Other prohibitionists, like Delgado and Stefancic (2004), do expressly advocate methods of combating intolerance beyond bans, including the development of educational materials and techniques. Unsurprisingly however, they, like Waldron, do little to distinguish the legitimacy of such methods from that of bans. Prohibitionists instead present their policies as a package that must include HSB-PD.

That failure to distinguish between democracy's minimal and optimising elements, i.e. between elements essential simply for a society to be a legitimate democracy, and those necessary or desirable for it to become an ever better democracy, later weakens Waldron's final chapter, in which he seeks to root his dignitarianism in the views of other classical liberals, such as Locke, Bayle, Voltaire and Diderot. There can be no doubt that those figures recognised the overall importance of mutual respect among citizens, including the inscription of that value within much of law. Such an aim is shared by oppositionists who advocate democracies' active, even coercive (e.g. through antidiscrimination law), yet non-viewpoint-punitive approaches to tolerance. That observation nonetheless differs from any view that those thinkers were theorising democracy's legitimating elements in casuistic detail, for the simple reason that they were living under aristocratic monarchies, not democracies. To the degree that such figures were theorising future democracies at all — which the admittedly liberal but nevertheless staunch royalist Voltaire, for example, certainly does not do, and which Diderot never does in any exhaustive or systematic way - it was far from their minds to be formulating legitimating rules in ways required for our LSPDs today.

I5 Anthony Lewis's all-too-common defence of free speech from the liberal perspective of focusing on punitive measures may have beguiled Waldron: see Lewis (2008). Lewis's error does not make Waldron right. It makes both of them wrong. 
Waldron rightly observes those philosophers' overall concern with human dignity; but we would need to reach almost Nietzschean extremes to find political theorists, ancient or modern, who do not share that concern in the purely general ways that Waldron recites. Enlightenment theorists have much to teach about ethics, law, justice and politics generally, but little to teach about the underpinnings of speech regulation in post-World War II LSPDs, the character and problems of which they never could have foreseen.

Rawls, by contrast, does investigate post-industrial democracies' legitimating features. Waldron more persuasively chooses him, rather than pre-twentieth-century theorists, as his primary point of reference. Waldron makes clear that he seeks no overall appraisal of the Rawlsian project. His stated interest lies solely in elements of law pertaining to the problems of hate speech. He invokes Rawls's notion of a 'well-ordered society' to ask whether such a place can accommodate the hostile and victimising social atmosphere generated by hateful expression. A 'well-ordered' society, Waldron argues, is one where citizens comply with a minimum code of mutual respect, where 'the bigots and racists give up their mission' (p. 78). Of course, that aspiration is only questionbeggingly, i.e. only derivatively or contingently deontological, given what in fact turns out to be its decidedly consequentialist assumption that HSB-PD-LSPD have any such effect upon 'the bigots and racists'. Again, like other prohibitionists, Waldron only assumes, never substantiates, such effects of HSB-PD-LSPD in rigorously empirical terms. The citizens, Waldron suggests, will then reject any social climate in which disrespect, at least taking excessive forms, can be displayed. What counts as excessive disrespect? While calling it a difficult notion, and claiming, along liberal lines, that he would resolve hard cases in favour of free speech (p. I26), Waldron deems the grossest manifestations, the crudest invective, to be generally apparent. (Waldron's analysis throughout the book is not generally 'intensive', relying on definitions of hate speech, but 'extensive', relying on examples of observed or reported incidents.)

Waldron's reasoning, then, is circular. Are HSB-PD necessary? It depends upon the requirements of a 'well-ordered society'. What is a 'well-ordered society'? Since Waldron refrains from discussing, let alone evaluating, any other Rawlsian elements, a 'well-ordered society' turns out in the book to be nothing more nor less than one that punishes HS-PD (pp. 65-69, 7I-8I). Waldron may seem at first glance to offer more. He suggests that Rawls's well-ordered society requires 'a conception of justice' (p. 78) and 'fundamentals of justice' (pp. 82, 83). Those 'fundamentals' or that 'conception' are, however, never specifically theorised or explored in Waldron's text, beyond his sheer insistence on a dignitarian trump in peremptory terms: 'discussion of a society with sufficient rancour and division to generate hate speech cannot be discussion of a well-ordered society' (p. 78, emphasis added). As a logical matter, that claim ought not to be Waldron's self-evident premise (if it were, there would be no need for the book, nor would his views ever have faced any credible opponents). It instead needs to be his conclusion, founded upon premises other than the bald assertion of the inherent evils, or harm, of hate speech.

Like any circular element in an argument, Waldron's appropriation of Rawls does not destroy the original premise of Delgado, Matsuda, MacKinnon and others that dignitarian concerns are important. Again, most leading oppositionists do not deny that age-old claim, which is why they support the non-viewpoint-punitive measures which the active democracy can take without having to resort to HSB-PD. So far, however, Waldron's argument fails to achieve what is clearly its nonconsequentialist aim, within his First Amendment analysis, of forging a dignitarian trump over democracy's legitimating condition of free speech within public discourse. The broader context of Waldron's discussion does nevertheless promise two ways out of that circular argument. One goes under the heading of 'legal realism', the other under the heading of what Waldron calls 'political aesthetics'. They can be taken in turn. 


\section{The pseudo-realist fallacy}

Waldron joins other US-based prohibitionists, such as Delgado and Matsuda, who purport to apply what is certainly a time-honoured American method, namely legal-realist analysis. American critical race theorists rightly invoke realism insofar as they observe that the US cannot be said to have provided - throughout much of its history of slavery, segregation and discrimination - equal expressive access within public discourse solely on grounds of the US Constitution's black-letter pledges of political equality. Delgado and Matsuda invoke a legal-realist method that they call 'outsider jurisprudence', which Waldron, too, employs, though rarely referring to it as such (possibly another sign of his preference for mainstream-liberal over critical discourses). Outsider jurisprudence, in all of these scholars' writings, draws on representative media reports, or individual narratives, in order to help the reader towards a feeling of empirically meaningful harm, while eschewing methodologically empirical comparisons of social conditions between countries that have and those that lack bans. (I should note that, even if I disagree with those scholars' recourse to HSB-PD-LSPD, I have praised and applied methods of outsider jurisprudence in other contexts; see, e.g., Heinze, 2009a, 2009b, 20I0, 20I3, pp. II4-43.)

Noteworthy in these scholars' putative realism is their literalist, often high-handed, self-styling as distinctly attuned to a human grittiness, a hipness that eludes their inevitably ivory-tower rivals (a long-familiar tactic in academia generally), and often phrased in comically butch terms, reminiscent of politicians' boasting about 'rolling up their sleeves' and 'doing the hard work', like 'ordinary' people. Hence Matsuda's pride in what she calls 'street wisdom' (I993, p. 50), or Waldron's entreaties that we examine what he calls 'the real world' (p. 82), or 'real-world societies here on earth' (p. Ior). Curiously, however, that is exactly where these scholars take a dubious turn. It is of course a platitude that on controversial issues all sides often rhetorically paint their opponents as 'out of touch' and their own views as the voice of some ineffably 'realistic' Everyman. More importantly, the point of those scholars' legal-realist critique is to ask whether formal legal guarantees correspond to on-the-ground realities. Having exhaustively turned that lens upon American law, they then glaringly abandon it, insisting wholesale upon the superiority of other countries' black-letter bans, without any such legal-realist attention to actual circumstances in the countries whose bans they endorse - which are analysed either not at all, or in purely cursory or anecdotal ways. I call that step the pseudo-realist fallacy.

One of Waldron's tactics is to challenge the anomaly of US law, being the only system within the family of modern democracies that rejects HSB-PD. Waldron recognises that his observation is not new: 'US versus the world' arguments have figured prominently in the views of prohibitionists since the I980s (see, critically, Heinze, 2008). Waldron does narrow the field by comparing American law with that of other 'advanced' democracies (p. 29), similar to what I am calling LSPDs, such as Germany and others. Waldron's context, then, is 'US versus Europe', with the European model standing, again, for Australia, New Zealand and other non-US LSPDs.

Waldron embraces the pseudo-realism common among US-based prohibitionists, insofar as they, in countless publications, constantly fail to compare like with like. They do not compare highminded, de-contextualised, purely-on-paper American ideals with high-minded, de-contextualised, purely-on-paper European ideals. Nor do they compare bleak, contextualised American realities with bleak, contextualised European realities. Instead, they take the transparent step of comparing the bleak, contextualised American realities only with the high-minded, de-contextualised, purelyon-paper European ideals. Along the lines of outsider jurisprudence, Waldron, like Delgado or Matsuda, cites copious examples of US intolerance. However, he then juxtaposes those with a sheer cutting-and-pasting of bans in their black-letter copy from countries that have them (pp. 8-9, I2-I5), with only, at most, brief and perfunctory references to intolerance in those 
societies - precisely the formalist move that prohibitionists dismiss as out of touch when free speech principles are cited in opposition to bans.

As if the result of such a 'comparison' could be in doubt, these analyses then applaud the LSPDs which have bans. Any similarly realist scrutiny of LSPDs with bans — like Germany or France, whose historical and social complexities make them valuable comparators for the US, and whose bans Waldron praises - is glaringly omitted, let alone the aforementioned evidence of bans as possibly active stimuli upon hate groups in Western Europe. The technique of rhetorical consequentialism, i.e. assuming without explaining the salutary effects of HSB-PD-LSPD, turns out to be even stronger in Waldron's than in Matsuda's or Delgado's writing, in view of Waldron's extended speculation about what a 'well-ordered society' with HSB-PD 'might' be like. He ignores the masses of evidence about what the societies whose bans he favours really are like. Writing a full two decades after Delgado's and Matsuda's first publications, Waldron certainly had the option of examining enormous bodies of evidence (as anyone who follows, for example, Belgian, Dutch, French, German, Scandinavian or Swiss media can attest, the coverage is constant) from the European jurisdictions whose bans he endorses. He, like his predecessors, does nothing of the kind. Waldron might well respond (also a curiously common tactic among prohibitionists) that continental European bans represent 'symbolic' advances, regardless of their real-world effects. If, however, the analysis is to proceed regardless of real-world effects, what was Waldron's purportedly realist intention in admonishing the rest of us to study 'real-world societies here on earth', as a means of coming to a purportedly legal-realist conclusion about the superior approach of democracies with bans?

Such analyses parade both as cosmopolitan-internationalist and as legal-realist, yet no serious comparative lawyer would credit the approach of contrasting deeply contextualised realities of one jurisdiction with the wholly de-contextualised, black-letter ideals of another. Delgado's, Matsuda's and Waldron's shared assumption — if they genuinely believe they are examining 'realworld societies here on earth' along legal-realist lines — seems to be that the US is the only society that needs any legal-realist analysis. Somehow France, Germany and other Western European states have already transcended legal realism, their sociopolitical reality wholly transubstantiated out of high-minded legal formalisms. The contrary, of course, makes more sense. If democracy $A$ does $x$, while every other democracy does $y$ because $y$ is better, then presumably there ought to be volumes of evidence documenting $y$ 's successes. What is troubling is not that these US-based scholars present no such evidence at all, so much as an all-too-familiar Anglocentric obliviousness about whether it is even worth bothering to look into evidence throughout the states of continental Western Europe, whose bans they repeatedly endorse, in any but fleeting and superficial ways.

Let us ask Waldron: Why must we examine the bad social effects of US First Amendment doctrine, while we need merely, uncritically assume the good effects of Western European bans? Does that tactic not merely presuppose the conclusions it ought to be explaining? Instead of criticising black-letter norms in view of actual conditions, as these scholars do for the US, they merely extrapolate actual conditions from black-letter norms. The only difference, in Waldron's case, is that he indicates that he was raised in New Zealand and then lived in Britain. Yet, leaving aside the difficulties of comparing New Zealand's population of fewer than five million with that of large and complex democracies containing tens or hundreds of millions, Waldron denies Britain, too, any serious legal-realist analysis, of the type Malik demands in Herz and Molnar (2009). In other words, rhetoric aside, Waldron's, like Delgado's or Matsuda's, dignitarianism was formalist, not realist, all along. HSB-PD are required not because these scholars can show Western European bans to have worked, but regardless of whether or not they work, or even make things worse. That is a curious way to vindicate legal realism, and, more importantly, an opaque way of vindicating human dignity. 
Waldron's resort to Rawls, heretofore puzzling as a matter of logic, now makes sense as strategy. Rawls's original aim was to sketch a large-scale model, in order to examine a series of broad, and, as presented, untested principles. He could plausibly claim that an abstract model, encompassing many elements of politics, was methodologically required, since no existing society offered all those elements in such a form. Waldron can make no such claim. Again, Waldron states that he requires no further political speculation, no model of law or politics as a whole, beyond those elements specifically pertaining to hate speech. Unlike Rawls's project, all other elements of familiar, liberal-democratic government Waldron leaves unexamined, as unnecessary for solving the problem at hand. Why would Waldron even bother with an abstract model, if he deems no political theorising beyond the scope of hate speech's 'social climate' to be necessary, and when evidence about intolerance in several of the societies whose bans he recommends is enormous?

If Delgado, Matsuda and Waldron genuinely believe in the principles of their legal-realist method, they cannot be unaware of the most basic and easily available facts pertaining to the states whose bans they praise. Since the late I980s, European democracies have steadily augmented both the scope and the implementation of their HSB-PD. Throughout that entire period, neither hate speech nor its supposed effects have diminished in the ways their ambitious claims for bans generally promise. In those states which most comprehensively and harshly punish racist and antisemitic speech, for example, such speech has nevertheless steadily increased to breath-taking post-War levels (see generally, e.g., Benz, 2005; Holz, 2005; Imbleau, 2003; Röpke and Speit, 2005; Schrank, 2006; Staud, 2006; Taguieff, 2002, 2004). Deeming it unnecessary to theorise beyond the scope of HS-PD, Waldron offers no hint as to why his 'well-ordered' society should avoid the same fate, adopting HSB-PD only to see intolerance subsequently explode. The only explanation seems to be that a purely idealised society - a society systematically theorised as not, or 'not yet' real, existing therefore anywhere but 'here on earth', and consisting only of the purified formalisms which these theorists' purported realism constantly warn against — remains forever sheltered from legal-realist evidence as to its success or failure.

Given that brand of legal realism, Waldron's reassurance that we 'should not think of a wellordered society', at least in the way he presents it, 'as a utopian fantasy' (p. 80) becomes difficult to swallow. Again, indicating early on his citizenship of New Zealand (p. 7, n. 4), Waldron includes that nation among those whose bans he endorses (pp. 8, 9, I3, 29, 45-46). To be sure, New Zealand has rightly been praised, in general terms, for its 'acknowledgement of the disadvantaged position in society of minorities' (United Nations, 2002). Is that why Waldron uncritically follows the tradition of aggregating 'the Europeans and the New Zealanders' (p. 9; cf. pp. 8, I3, 29)? He certainly never distinguishes them. Yet surely Waldron cannot think, along simplistic 'US versus the world' lines, that a positive record about New Zealand's overall approach to minorities suddenly stands as a proxy for the specific effects of HSB-PD throughout complex Western European democracies.

Why, then, must we spend our time 'imagining a society on the way to becoming well-ordered' (p. 83) when, unlike Rawls, the only norm Waldron indicates as relevant to that society, i.e. HSB-PD, has been achieved, with Waldron's enthusiasm? In view of the evidence, accumulating over decades, of extremist activity in Europe, Waldron's two-sentence dismissal of concerns about driving hate groups underground ends up at odds with his exhortations to realism: 'It is sometimes objected', he writes, that bans 'simply drive hate underground. But in a way, that is the whole point: we want to convey the sense that the bigots are isolated, embittered individuals' (p. 95). On the evidence, as even prohibitionists studying Europe have had to concede (see Imbleau, 2003, pp. I77, I83-84), Western European HSB-PD do anything but leave 'bigots ... isolated'. 


\section{The decorum fallacy}

While offering no further comment on Rawls's concept of the 'well-ordered society', which might have provided the anterior deontological principles necessary to avoid a circular reliance on Rawls, Waldron does propose his own version of that concept, still in an attempt to ground such principles. He presents his conception under a banner that he labels 'political aesthetics' (pp. 7I-75). I have spoken to more than one reader who doubts whether Waldron intends this element of his thesis to carry much weight. Given in particular Waldron's earnest reliance on Edmund Burke, however, he drops no hint that he means something other than what he says.

One might wonder whether Waldron means 'aesthetic' only in the colloquial sense of sensorially or atmospherically pleasant. It might be worthwhile for us to read the concept that way, since many prohibitionists still continue to make the old decorum arguments, particularly in less theoretical contexts. The traditional decorum justifications stem from the days when regulation of provocative speech was deemed a routine state prerogative, in a world scarcely mindful of citizens' democratic prerogatives, a world recognising 'human rights' of speech either not at all, or only in gestural ways, and therefore willing to subject free speech to straightforward balancing against any and every restriction deemed by some empowered authority to be 'reasonable' (see, e.g., Post, 2009, I995, pp. I28-34, 268-89, 300-02; Weinstein, 2009a, pp. 55-58). Vladimir Putin is by no means alone on the world stage in arguing, with Waldron (who, of course, would differ on questions of implementation), that '[a] civilised dialogue is only possible with those political forces who put forward, justify and formulate their demands in a civilised manner' (Russia News, 20I2). What is notable about that statement is that it, too, strategically advocates limits on freedom within liberalism's own age-old self-appropriations of the mantle of 'civilisation', as a self-evident concept. Several passages in Waldron's book strongly echo that ostensibly liberal point. Such declarations betray the uncritical assumption of how-could-things-be-otherwise obviousness, which, as I shall argue in a moment, Waldron builds into his particular version of "political aesthetics'.

The predictable objection to the old decorum arguments, as Waldron would know, is that we abandon all talk of a democratic, or higher-law right or prerogative of speech at all, if sheer appeals to decorum suffice to override it. Parallel to Waldron's turn away from expressly causal arguments, he seeks to root his dignitarianism in soil more fertile than that of the conventional decorum arguments, since he would scarcely require so grand a concept as 'political aesthetics' if his only aim were to revive those familiar claims. Waldron indeed emphasises that his 'political aesthetics' are not merely 'for the sake of ... a pretty display' (p. 83). He has no pedestrian aesthetics in mind, but rather an aesthetics in some critically grounded, even legally foundational sense. That project can certainly claim a distinguished vintage, as the history of politically conscious aesthetic theory - to which, curiously, Waldron makes no broader reference - dates back to Plato, and recurs in thinkers as varied as Aristotle, Rousseau, Hegel, Brecht, Benjamin or Derrida.

If Waldron means 'aesthetics' neither in the conventional nor in that theorised way, then he would have little reason to assume that we know how he means to use it, as he never explains any other sense of the term. Since the conventional decorum arguments, in a modern democratic legal order, run into such well-known difficulties, we can only assume, by process of elimination, that Waldron does have some theorised aesthetics in mind. Delgado and Stefancic had already discussed the importance of public imagery (pp. 72-73). Once again, citing insights from American critical race theorists, Waldron seeks a dignitarian trump by shifting those concerns to mainstream liberal theory, while 'trying to proceed in the spirit of the concerns [Delgado and Stefancic] raise' (p. 73). 
Aesthetic perspectives, of the more theorised type, can undoubtedly illuminate hate speech debates. They dramatise questions of intolerance, dissidence, exclusion, and their social contexts, as works like Othello or The Merchant of Venice remind us (see, e.g., Heinze, 2009a, 2009b, 2013, pp. II4-43). Colossal questions arise however - although Waldron never acknowledges that this is a stunning step in his argument - about whether aesthetic theory delivers unambiguous resolutions to the specific, black-letter problems with which his book is concerned, namely whether a given jurisdiction is better off with HSB-PD. There is certainly a long tradition of politicians and jurists citing the arts in offhand ways. But it is no small matter for the adoption or rejection of a set of norms, pitched at such a specific level, to draw so centrally from aesthetic theory. Yet that is what Waldron's 'political aesthetics' purports to do, in order to elucidate his otherwise circular, and therefore still un-theorised, recourse to the concept of the 'well-ordered society'.

There is nothing wrong with being the first to do something. But readers may wonder why Waldron seems unaware of the threshold problems that arise from his casually assumed premise, namely that black-letter norms can ultimately be derived from aesthetic theories. The notion of a normative aesthetics, which yields not only an ethical direction or sensibility, but precise legal rules, counts among this book's notable innovations. In remarkably few pages, Waldron not only undertakes that enterprise, but presents it as surprisingly straightforward, requiring no prior assessment as such before embarking upon his particular version of aesthetics. After all, aesthetic concepts entail some of philosophy's most intricate problems. There is a vast array of theories, often mutually incompatible. That problem, too, does not detain Waldron, as he never mentions any theory but his own, as if the others self-evidently cannot provide alternative responses to the questions for which he invokes aesthetic principles. Some of those other theories (in my view, most of the serious ones) can be marshalled just as strongly in support of or in opposition to bans, or, rather, suggest no particular resolution at all. For what it is worth, my advice would be to steer away from aesthetics as such a central factor in determining whether or not to adopt HSB-PD (or just about any other legal problem calibrated at that level of positive-law precision), even if they do help to vivify analyses of socio-legal problems in more general ways.

My gut therefore still wants me to join with those readers who think Waldron is not actually trying to add much in this discussion. Yet there seems no other way out of his circular concept of the 'well-ordered society', and he certainly insists on according aesthetic theory that central role for the concept's exegesis. He asks repeatedly, in aesthetically evocative terms: 'What should a well-ordered society look like?', 'What should a well-ordered society sound like?' (original emphasis). Even 'smell' is thrown in (pp. 68-69, 71, 73, 74, 76, 83, 98). I wholeheartedly agree that the non-verbal, as well as the symbolism within and beyond the verbal, is central to law and politics, as is cogently illustrated by many scholars within the law and humanities movement. In any scholarly enquiry, aesthetics being no different, it would nevertheless seem precarious to trumpet a centuries-old theory without even acknowledging the kind of theory one is embracing, nor noticing perennial objections to it.

Waldron opts for a set of aesthetic assumptions well known, although he never presents his selection in any such historiographically conscious way, as starting and stopping with eighteenthcentury neoclassicism. He voices that preference through the mouth of Edmund Burke. Waldron overlooks age-old criticisms of, for example, neoclassicism's assumptions of objective beauty, which had indeed dictated corrections to what Waldron calls 'ugly ... reality' (p. 65), along with an elimination of the 'disfiguring' of 'our social environment' (p. 33). Without apparent irony, Waldron goes so far as to write:

'A general consideration of what a well-ordered society looks like, sounds like, smells like, and feels like might be an exercise in political aesthetics — the sort of thing we find in Edmund 
Burke's observation that "[t]o make us love our country, our country ought to be lovely," and in his talk about "the pleasing illusions, which [make] power gentle, and obedience liberal, ... the superadded, ideas, furnished from the wardrobe of a moral imagination, which the heart owns, and the understanding ratifies, as necessary to cover the defects of our naked, shivering nature, and raise it to dignity in our own estimation.' (p. 74) (Waldron emphasises 'general'; all other emphases are added)

Burke lived through the heyday of restorations of ancient statuary ruins, popular among the privileged English aristocracy (see Coltman, 2006). Right-minded Enlightenment technicians added arms and legs to make fragments look 'normal', lest their, to use Waldron's word, 'disfiguring' should appear monstrous or frightening. Take note in that passage even of Burke's - Waldron's - metaphor of nakedness as indignity, in contrast to a 'wardrobe', an amenity of privilege for most of Europe's eighteenth-century populations. Undistinguished as an aesthetic philosopher, Burke simply recapitulates conventional, class-driven opinion of his time. Neoclassicism will admit only idealised nudity, while that of any ordinary, recognisable and defective human being is deemed hideous (a dogma later famously vandalised by Manet's Le déjeuner sur l'herbe (I863)). In what verges on an art-school caricature of the sanitised-and-bleached, establishment-approved academic style, which would later spark the ire of Romanticism and then Modernism - De Chirico had spoofed it a century before it would inspire Waldron, in such works as Love Song (I9I4) and Piazza with Apollo and Ariadne (c. I9I3) - we find all neoclassicism's predictable earmarks, not omitting Burke's many 'pleasing illusions':

'Political aesthetics invites us to think about such things as monuments, cenotaphs, public statues ... Or ceremonies (coronations, inaugurations, armistice day, etc.) ... Or costumes, like wigs, gowns, and uniforms in the administration of justice. We can think about the visible display of power, including the presence and bearing of uniforms of police and security forces, about flags and banners, and civil and military parades.' (p. 75, emphasis added)

Waldron 'invites us' twice in that passage to 'think about' the 'visible display of power'. Yet he offers none of his own critically minded thoughts about the age-old objections levelled against the premodernist assumptions of his political aesthetics. I am by no means demanding that Waldron expressly embrace the technical term 'neoclassical' or any other standard vocabulary of philosophical aesthetics. Nor am I suggesting that his analysis requires him to locate its rather conspicuous origins within any articulated history of eighteenth-century aesthetics. To the contrary, it speaks volumes for the overwhelming power of high-bourgeois neoclassicism that it can have pervaded so much of our culture's worldview as to appear to the elite not as an historical product, but, like Putin's 'civilisation', simply as a kind of everyday and healthy common sense.

Rather, I am making only the more obvious point that when a theory is proposed which does claim such a conspicuous historical vintage (or which so strongly resembles or alludes to one that does), we ordinarily expect the theorist to have at least the main, traditional, objections to that theory in mind, and to offer some response to them. Assume that a given author were to propose, as an ideal society, one that just happened to consist of a 'polis', policed by an elite 'guardian' class, whose education began with song and dance and continued through to other kinds of knowledge, and was headed up by 'philosopher rulers', whose insights into justice were achieved through 'dialectical' contemplation of 'eternal Forms'. At some point we would have to say: 'Surely there is a precedent, a history, and some standard objections, lurking behind your proposal.' And 
it would be astonishing for that theorist to reply" 'Well, I'm just not dealing with those. I'm asking only for my theory to be taken on "its own" terms.'

In our post-constructivist world, immersed in Modernist critiques certainly since the early twentieth century, yet already emerging in the mid nineteenth, Waldron uncritically assumes 'civilised', neoclassicist aesthetics not only to be taken for granted as a kind of cognitive universal, but also as a source so obvious and determinate as to generate a verdict about twenty-first-century hate speech debates. Waldron's only apparent awareness of any critical context collapses into a snappy rebuke to liberals who 'love ... the untidiness of the marketplace of ideas' (p. 67), as if aesthetic theory were nothing more than the effluence of lawyerly policy debates. Waldron's foray into the world of aesthetics fails to spur him on to pondering anything like the masses of critically grounded, post-expressionist, let alone post-Brechtian theories, which not only shun 'pleasing illusions', but which challenge assumptions that it is 'necessary to cover the defects of our naked, shivering nature' (see generally, e.g., Brecht, I957; Derrida, I967a, I967b). The 'aesthetics' Waldron prefers for his 'well-ordered society' translates into neoclassicism's comforting political world of Gilbert Stuart or John Trumbull, not into the socio-critical world of Kafka, Rilke, Magritte, Schiele, Prokofiev or Bartok. Even Breughel, Bosch, Chaucer, Rabelais, Shakespeare or Middleton had, over a century earlier, already surpassed, in sheer acuity, the aesthetics of Waldron's Burke. Et bren, bren! dist Pantagruel .... Quite frankly, if one wishes to justify the kinds of limits Waldron seeks on individual expression, then Western aesthetic theory, if one is not simply making a mockery of it, is arguably the last place to look, let alone to do so in such an offthe-cuff and de-contextualised way.

Waldron might hasten to add: 'But of course, my society would allow Kafka, Rilke, Breughel, Bosch, Shakespeare and all those others!' Yet any such rejoinder would give his game away. He claims to invoke Burke not just to ascertain specific norms, but to explain the 'look', 'sound', 'feel' and 'smell' of that 'well-ordered society' which HSB-PD are intended to achieve, and to do so in a way specific enough to support (again, leaving aside whether this amounts to 'advocacy' of) punitive legal prescriptions. After all, if the only role of 'political aesthetics' is to eliminate hate speech, then that element of the argument becomes circular too and, like the Rawlsian import, redundant. Do we need hate speech bans on public discourse? It depends on our 'political aesthetics'. What are our 'political aesthetics'? Nothing more nor less than the kind that requires hate speech bans on public discourse. Waldron's aesthetics can only avoid that vacuity by showing us the 'look', 'sound', 'smell' or other ingestions of his 'well-ordered society' to at least some non-trivial extent beyond assuming its own conclusion, i.e. the legal punishment of hate speech.

It is remarkable that Waldron's premises, referencing the surface radicalism of critical race theory, so handily give birth to Burke's tapestried conventionalism. In the self-same breath again, without apparent irony - in which Waldron assures us that his 'political aesthetics' are not merely 'for the sake of ... a pretty display' (p. 83), he invokes 'the decent drapery celebrated by Edmund Burke' (p. 83), as apparent signifier of the 'decent society' (p. 94). (One might wonder whether traces of Rousseau's 'dangerous supplement' stealthily glimmer from that upholstery (see Derrida, I967a, pp. 203-34).) It seems that Malcom X's street riots miraculously finish out the afternoon in a Georgian tea salon. Waldron's Burkean interior cries out to be compared with artists, like Heinrich Mann, whose Der Untertan (or indeed his Professor Unrat), a century ago, had already portrayed Burke's straitjacketed traditionalism not as an antidote against narrowmindedness, but as the toxin that induces it.

Either Delgado's and Matsuda's insights, far from being critical, have assumed uncritically conventional values all along, or Waldron's aesthetics also 'cover the defects' of some deep disagreements with critical race theory on what exactly human dignity is. Given that Waldron's book fails to advance their views in the way his Rawlsian model sought to do, both his supposed 
legal realism and his 'political aesthetics' make it unclear which dignitarian claims we are expected to believe, let alone how all of these haphazardly theorised concepts of dignity can, within the book's First Amendment context, ever deliver any trump over democratic citizens' fundamental prerogatives of speech within public discourse. If human dignity is such a self-evident and paramount value — as, again, I along with several other oppositionists agree it is, to the extent of non-viewpoint-punitive but active democracy - one wonders why these scholars must spend their time contriving such obtuse arguments in search of that foundation.

Also germane to Waldron's panorama - although, once again, the book treats its aesthetics ahistorically, as if cognitively natural and obvious - is the eighteenth century's continuation of the landscape tradition, first associated with Claude, Cuyp then Constable, and even assimilated into stately portraiture, as in Gainsborough's The Duke and Duchess of Cumberland (1785). The topical revival of that aesthetics resonates throughout Waldron's rhythmically reiterated reminders of the 'environment', the 'atmosphere', the 'landscape', the 'ecology', which, without HSB-PD, suffer 'ugliness' and 'disfiguring. ${ }^{16}$ Like the transfiguration of supposedly radical race theory through the filter of Rawls, Waldron absorbs the erstwhile rebellious cachet of environmentalism within Burke's drawing-room respectability.

Let us shift our gaze away from such schoolbook neoclassicism, back to the twenty-first century. A broader appreciation of aesthetic theory discloses a more intricate human world. That world seems scarcely amenable to solving social problems by 'covering the defects'. To be sure, Hegel, scolding Romanticism, had praised the art and architecture of our democratic Greek and republican Roman ancestors. Hegel rightly admired their deeply public function, as expressions of full citizen involvement in self-government (1970, pp. I2-107), perhaps unmatched in the West to this day. The Burkean Enlightenment had looked back in awe upon those achievements, seeking to revive them as much in aesthetics as in politics, as we see today in the historic neighbourhoods of Berlin, London, Paris or Washington, DC, even if Burke's version belongs less to Greece or Rome, and more to a proto-Victorianism. I am far from underestimating Hegel's admiration for the classical legacy of the political aesthetics of the civically minded citizen.

It is no accident that Plato and Aristotle had assigned a central role to aesthetics, in what we would later call its classical forms, in the life of the polity. In that sense, Waldron's approach although he never recognises it as such — hearkens back to the origins of Western political philosophy. Again, Plato assigns 'political aesthetics' a foundational role in the Republic. It cannot be sheer coincidence that, from the youngest age, those citizens too are educated by 'covering the defects' in a 'decent drapery': 'if anyone composes a poem about ... the tale of Troy ... we must require him to say that these things are not the work of a god' (I997, p. IoI 8). Plato admonishes 'we'll admit only the pure imitator of a decent person' (I997, p. I034, emphasis added; see generally I997, pp. I0I5-40), who will not 'mix' acceptable with unacceptable elements. To avoid any 'creepy totalitarian flavour' (p. 87), Waldron once again simply assumes his conclusion: he limits 'decent' to signify neither more nor less than precisely that which is required under HSB-PD. Like Waldron's 'well-ordered society', his 'political aesthetics', bereft of any further critical detail or context, again end up telling us little more about either aesthetics or politics than that they just happen to require HSB-PD-LSPD.

The closer we look at Waldron's 'well-ordered society', the harder it is to see. It is Rawlsian, but it is not. It is legal-realist, but it is not. It shuns a 'pretty display', while demanding 'decent drapery'. If human dignity does indeed claim the peremptory ethical, legal, political and cultural status that Delgado, Matsuda or Waldron attribute to it, one wonders why they send the rest of us down paths which they themselves show little desire to travel. They promise half a dozen ways to

I6 Equally worth comparing is Waldron's 'slow-acting poison' with Derrida's view of Plato’s phármakon, the potion that both cures and kills; see Derrida (I972). 
combat intolerance, yet show us no single spot to plant their dignitarian justification for viewpointpunitive rules within public discourse. Small wonder when Weinstein and Hare (2009, p. 7, n. 26) grumble that defences of hate speech bans are 'under-theorized and rely on a shifting collection of justifications relating to public peace and order, non-discrimination, offensiveness, and human dignity, often without any principled attempt to separate them out'.

Be that as it may, and having considered what appear to be some problems in Waldron's approach, Waldron's monograph remains lucid and accessible, and will surely exert influence in prohibitionist circles. I have also tried to convey some of the richness of Herz and Molnar's text, and it offers much more. Readers interested in a serious, detailed, often lively, comparative study of hate speech, from a variety of helpful perspectives, will rank Herz and Molnar's anthology among the most important publications to date. Each of its twenty-six chapters offers some new insight. Even if Molnar's opposition to bans, through his active presence in the various interviews, probably tilts this collection in a First Amendment direction, many of the leading arguments not only opposing but also favouring bans enjoy a full, fair and most interesting hearing.

\section{References}

BAKER, C. Edwin (2009) 'Autonomy and Hate Speech', in Ivan Hare and James Weinstein (eds), Extreme Speech and Democracy. Oxford: Oxford University Press, I39-57.

BBC NEWS (2006) 'Protester “called for beheadings"'. Report of 2 November 2006. Online: <http://news. bbc.co.uk/I/hi/uk/6II3874.stm> (last accessed Io November 2013).

BENZ, Wolfgang (2005) Was ist Antisemitismus? (2nd edn). Munich: Beck.

BOyLE, Kevin (200I) 'Hate Speech: The United States versus the Rest of the World?', Maine Law Review

53: 487-502.

BRECHT, Bertholt (I957) Schriften zum Theater: Über eine nicht-aristotelische Dramatik. Frankfurt am Main:

Suhrkamp.

BretTschneider, Cory (2012) When the State Speaks, What Should It Say? How Democracies Can Protect

Expression and Promote Equality. Princeton: Princeton University Press.

BUTLER, Judith (1997) Excitable Speech: A Politics of the Performative. New York: Routledge.

Coltman, Viccy (2006) Fabricating the Antique: Neoclassicism in Britain. Chicago: University of Chicago Press.

DELGADO, Richard and STEFAnCIC, Jean (2004) Understanding Words that Wound. Boulder, CO: Perseus. DERRIDA, Jacques (I967a) De la grammatologie. Paris: Éditions de Minuit.

DERRIDA, Jacques (I967b) L'Écriture et la difference. Paris: Éditions du Seuil.

DERRIDA, Jacques (I972) ‘La pharmacie de Platon', in Jacques Derrida La dissémination. Paris: Éditions du

Seuil, 77-2 I3.

DWorkIn, Ronald (2009) 'Foreword', in Ivan Hare and James Weinstein (eds), Extreme Speech and

Democracy. Oxford: Oxford University Press, v-ix.

FENwick, Helen (2002) Civil Liberties and Human Rights. 3rd ed. Oxford: Routledge.

FISH, Stanley (1994) There's No Such Thing as Free Speech: And It's a Good Thing, Too. New York: Oxford

Paperbacks.

GRIMM, Dieter (2009) 'Freedom of Speech in a Globalized World', in Ivan Hare and James Weinstein

(eds), Extreme Speech and Democracy. Oxford: Oxford University Press, I I-22.

HARE, Ivan and WeInStein, James (eds) (2009) Extreme Speech and Democracy. Oxford: Oxford University Press.

HEGEL, Georg Wilhelm Friedrich (I970 [1835-38]) 'Vorlesungen über die Ästhetik I', in Georg Wilhelm

Friedrich Hegel: Werke (Vol. I3). Frankfurt: Suhrkamp.

HeInze, Eric (2008) 'Truth and Myth in Critical Race Theory and LatCrit: Human Rights and the Ethnocentrism of Anti-Ethnocentrism', National Black Law Journal 20: 107-62. 
HeInze, Eric (2009a) 'Imperialism and Nationalism in Early Modernity: The "Cosmopolitan" and The

"Provincial" in Shakespeare's Cymbeline', Journal of Social and Legal Studies I8: 139-68.

HEINZE, Eric (2009b) “Were it not against our laws": Oppression and Resistance in Shakespeare's

Comedy of Errors', Legal Studies 29: 230-63.

HeInze, Eric (2010) "He'd turn the world itself into a prison": Empire and Enlightenment in Jean

Racine's Alexander the Great', Law and Humanities 4: 63-89.

HEINZE, Eric (2013) The Concept of Injustice. London: Routledge.

HeInZE, Eric (20I4, forthcoming) Citizenship Unmodified: Democracy and the Problem of Hatred.

holz, Klaus (2005) Die Gegenwart des Antisemitismus. Islamistische, demokratische und antizionistische

Judenfeindschaft. Hamburg: Hamburger Edition.

IMBLEAU, Martin (2003) La négation du génocide nazi, liberté d'expression ou crime raciste?: Le négationnisme

de la Shoah en droit international et comparé. Paris: L'Harmattan.

LEBRETon, Gilles (1999) Libertés publiques et droits de l'homme (4th edn). Paris: Armand Colin.

LEwIs, Anthony (2008) Freedom for the Thought We Hate: A Biography of the First Amendment. New York:

Basic Books.

Matsuda, Mari J. (I993) 'Public Response to Racist Speech: Considering the Victim’s Story', in Mari

J. Matsuda, Charles R. Lawrence III, Richard Delgado and Kimberlé Williams Crenshaw (eds)

Words That Wound: Critical Race Theory, Assaultive Speech, and the First Amendment. Boulder, CO:

Westview Press, I7-5I.

matsuda, Mari J., Lawrence, Charles R. III, Delgado, Richard and crenshaw, Kimberlé Williams (eds)

(I993) Words That Wound: Critical Race Theory, Assaultive Speech, and the First Amendment.

Boulder, CO: Westview Press.

MILL, John Stuart (I982 [1869]) On Liberty, ed. G. Himmelfarb. London: Penguin.

mirovalev, Mansur (2013) 'Russia Moves to Enact Anti-gay Law Nationwide', Yahoo! News report of 2 I

January 2013 (Associated Press). Online: 〈http://news.yahoo.com/russia-moves-enact-anti-gay-

law-nationwide-I2582505I.html> (last accessed ro November 2013).

PLATo (I997 [c. 380 BC]) Plato: Complete Works, ed. J. M. Cooper. Indianapolis, IN: Hackett.

post, Robert (1995) Constitutional Domains: Democracy, Community, Management. Cambridge, MA:

Harvard University Press.

POST, Robert (2009) 'Hate Speech', in Ivan Hare and James Weinstein (eds), Extreme Speech and

Democracy. Oxford: Oxford University Press, I23-38.

POST, Robert (20II) 'Participatory Democracy and Free Speech', Virginia Law Review 97: 477-90.

RAWLS, John (I999) A Theory of Justice (2nd edn). Oxford: Oxford University Press.

ROBERT, Jacques and DUfFAR, Jean (I 996) Droits de l'homme et libertés fondamentales. Paris: Montchrestien. RÖPKE, Andrea and SPEIT, Andreas (2005) Braune Kameradschaften. Die militanten Neonazis im Schatten der

NPD (2nd edn). Berlin: Links Verlag.

Russia news (2012) 'Putin Denounces Opponents Who Receive Foreign Aid.' Report of I 2 December

20I2. Online: 〈http://www.russianews.net/index.php/sid/2I I339569/scat/72397Id98I6od438〉

(last accessed io November 2013).

schrank, Carsten (2006) Rechts-Staat Deutschland? Zum Kampf der Justiz gegen Rechtsextremisten .

Norderstedt: Books on Demand.

STAud, Toralf (2006) Moderne Nazis: Die neuen Rechten und der Aufstieg der NPD (3rd edn). Cologne:

Kiepenheuer und Witsch.

TAGUieff, Pierre-André (2002) La Nouvelle judéophobie. Paris: Mille et Une Nuits.

TAGUIEFF, Pierre-André (2004) Prêcheurs de haine: Traversée de la judéophobie planétaire. Paris: Mille et Une

Nuits.

United nations (2002) Report of the Committee on the Elimination of Racial Discrimination. New York: United Nations. 
vaneigem, Raoul (2003) Rien n'est sacré, tout peut se dire: Réflexions sur la liberté d'expression. Paris: La Découverte.

WALDRON, Jeremy and weInstein, James (20I2) The Legal Response to Hate Speech: Should the U.S. be more like Europe? Available at: 〈http:/online.law.asu.edu/Events/201 2/HateSpeach/〉

weinstein, James (2009a) 'Extreme Speech, Public Order, and Democracy', in Ivan Hare and

James Weinstein (eds), Extreme Speech and Democracy. Oxford: Oxford University Press, 23-6r. weinstein, James (2009b) 'An Overview of American Free Speech Doctrine and its Application to

Extreme Speech', in Ivan Hare and James Weinstein (eds), Extreme Speech and Democracy. Oxford: Oxford University Press, 8I-95.

WEINSTEIn, James and HARE, Ivan (2009) 'General Introduction', in Ivan Hare and James Weinstein (eds), Extreme Speech and Democracy. Oxford: Oxford University Press, I-7.

WIJNBERG, Robert (2008) In Dubio: Vrijheid van meningsuiting als het recht om te twijfelen. Amsterdam: Prometheus. 